\title{
Bacterial and antibiotic susceptibility pattern of urinary tract infection isolated from asymptomatic and symptomatic diabetic patients attending tertiary hospital in Jos, Nigeria
}

\author{
Joseph Aje Anejo-Okopi ${ }^{1 *}$, Ocheme Julius Okojokwu', Seljul Mamzhi-Crown Ramyil ${ }^{2}$, Panshak Barnabas Bakwet ${ }^{1}$, Juliet Okechalu ${ }^{1}$, \\ Godwin Agada ${ }^{3}$, Paul Amos Bassi ${ }^{4}$ and Segun David Adeniyi ${ }^{5}$ \\ ${ }^{1}$ Department of Microbiology Faculty of Natural Sciences University of Jos, Nigeria \\ ${ }^{2}$ Department of Medical Microbiology and Parasitology College of Medicine and Health Sciences Bingham University, Jos, Nigeria \\ ${ }^{3}$ Central Diagnostic Laboratory National Veterinary Research Institute Vom, Jos, Nigeria \\ ${ }^{4}$ Department of Community Medicine and Primary Health Care, College of Medicine and Health Sciences Bingham University Jos, Nigeria \\ ${ }^{5}$ Infectious Diseases Unit, Jos University Teaching Hospital, Jos, Nigeria
}

\begin{abstract}
Urinary tract infection (UTI) is an infection caused by the presence and growth of microorganisms in the urinary tract. In most cases empirical antimicrobial treatment is usually initiated before the laboratory results are made available; hence the need for antibiotic susceptibility test to enhance management of UTI. The study was designed to determine the bacterial profile and antibiotic susceptibility pattern of urinary tract bacteria isolated from symptomatic and asymptomatic diabetic patients at Bingham University Teaching Hospital Jos. 100 mid-stream urine samples (app. 20 mls) were aseptically collected into sterile containers after informed consent of diabetic patients of ages 20 years and above were analyzed at Central Diagnostic Laboratory NVRI Vom. The isolates were identified using standard bacteriological techniques after been cultured on MacConkey and CLED agars. Antibiotic sensitivity testing was done in accordance with NCCLS disc diffusion methods. The results were then analyzed using chi square test. Of the 100 urine samples, different bacterial uropathogens were isolated, with a prevalence of $40 \%$. The bacteria isolates were; Coagulase negative Staphylococci (CNS) (37.5\%), Escherichia coli (24\%), Klebsiella pneumoniae (12.5\%), Staphylococcus aureus (15\%) and Streptococcus spp (10\%). Esherichia coli and Klebsiella pneumoniae were highly resistant to most antibiotics used, while coagulase negative staphylococci, Staphylococcus aureus and Streptococcus spp were highly sensitive to most antibiotics used in this study. Self-medication including antibiotics is clearly a major culprit. Behavioral Change Communication to all stake holders is increased to cover all radio and TV stations in the state. In addition, investigations (routine microscopy, culture and sensitivity of urine) be completed before treatment is commenced in order to mitigate acquisition and spread of drug resistance by bacteria.
\end{abstract}

\section{Introduction}

Background of the study: Urinary tract infection (UTI) is caused by the presence and growth of bacteria in the urinary tract. It is thus, the single and most common bacterial infections of mankind [1,2]. Urinary tract infections are among the most common infections in both gender and has been reported also in all age group Anatomically, women have shorter urethra than men [3-5]. In addition, bacteria from rectum can easily travel up to the urethra and cause urinary tract infections $[2,6]$.

Diabetes mellitus has long been considered a predisposition factor to urinary tract infection and urinary tract is the primary site of the infection with an increased risk of complications $[7,8]$. The risk factors of urinary tract infections in patients with and without diabetics have been identified as; Obesity, female sex, male prostrate syndrome, low immunity, glucosuria and bladder dysfunction. Hyperglycemia also contributes to the colonization of different kind of microorganisms in the urinary tract $[9,10]$.

Klebsiella, Staphylococci, Enterobacter, Proteus, Pseudomonas and Enterococci species are more often isolated from in-patients, whereas, there is greater predominance of Escherichia coli in outpatients and anaerobic organisms are rarely pathogens in the urinary tract while Coagulase Negative Staphylococci tend to cause infection in young Women of sexually active age [11-13]. The emergence of antibiotic resistance in the management of urinary tract infection is a public health concern particularly in the developing countries, apart from high level of poverty, ignorance, poor hygienic practices and wide circulation of fake and spurious drugs in the markets [14].

The prevalence of Diabetes mellitus is increasing worldwide, and the emergence of multi-drug resistance strains of bacteria, hence the need to isolate, characterize and determine the antibiotic susceptibility pattern of bacteria associated with UTI. However, different species of bacteria have been found colonizing the urinary tract of diabetic

Correspondence to: Joseph Aje Anejo-Okopi, Department of Microbiology Faculty of Natural Sciences University of Jos, Nigeria, E-mail: josephokopi@ yahoo.com

Key words: antibiotic susceptibility, urinary tract infection, diabetics, symptomatic and asymptomatic

Received: November 04, 2017; Accepted: November 20, 2017; Published: November 23, 2017 
Anejo-Okopi JA (2017) Bacterial and antibiotic susceptibility pattern of urinary tract infection isolated from asymptomatic and symptomatic diabetic patients attending tertiary hospital in Jos, Nigeria

patients due to low immunity, glucosuria, bladder dysfunction and depletion of local urinary cytokine secretion; hyperglycemia attracts enteric bacteria to the urinary tract and thus treatment of urinary tract infection among diabetic patients is necessary.

The study aim was to determine the bacterial profile and antibiotic susceptibility pattern of urinary tract bacteria isolated among symptomatic and asymptomatic diabetic patients at the Bingham university teaching hospital Jos.

\section{Materials and method}

\section{Study site and population}

The cross-sectional study was carried out at the out patients' unit accepting suspected diabetic patients at Bingham University Teaching Hospital and the laboratory procedure was at Microbiology Laboratory, Central Diagnostic Laboratory National Veterinary Research Institute, Vom. The study enrolled 100 adults $\geq 20$ years (50 asymptomatic and 50 symptomatic) patients.

\section{Ethical approval}

Ethical clearance was obtained from the Health Research and Ethics Committee of Bingham University Teaching Hospital Jos. All the patients were given an informed consent alongside structured questionnaire for both males and females diabetic patients including assessment of socio-demographic data, risk factors and disease knowledge.

\section{Sample collection and transportation}

Clean catch mid-stream techniques were employed to collect the urine samples (app. $20 \mathrm{mls}$ ) aseptically by each diabetic patient in a sterile wide mouthed container after informed consent of the patients was obtained, each of the samples in the container were well labeled appropriately and were transported in an ice bag to the Central Diagnostic Laboratory NVRI Vom for culture.

\section{Laboratory procedure}

The sterile urine samples were thoroughly mixed for even distribution of organisms; a loopful of the urine was inoculated onto the surfaces of MacConkey and Cysteine lactose electrolyte deficient (CLED) agar plates then incubated aerobically at $37^{\circ} \mathrm{C}$ overnight. The isolates were identified using standard bacteriological techniques. Antibiotics sensitivity testing was done on sensitivity test agar using disc diffusion methods in accordance with National Committee for Clinical Laboratory Standards [15]. The diameter of the zone of inhibition around the disc was measured to the nearest millimeter. The results of the antibiotic susceptibility test were then compared [16].

\section{Results}

Significant bacteria were isolated in 40/100 (40\%); (65\%) and (35\%) of symptomatic and asymptomatic diabetic patients respectively $(\mathrm{P}<0.05)$. Prevalence of bacteria isolated among the symptomatic patients: E. coli (19.2\%), CNS (46.15\%), K. pneumoniae (19.23\%), S. aureus (3.84\%), and Streptococcus spp. (11.53\%) while that of the asymptomatic was; E. coli (31.25\%), CNS (18.75\%), S. aureus (31.35\%), and Streptococcus spp. (6.25\%) (Table 1).

Socio-demographic (Table 2) variables analyzed showed that among the symptomatic group $36 \%$ have family history of being diabetic, whereas $64 \%$ do not have family history of diabetics while $80 \%$ have weight greater than $61 \mathrm{~kg}, 82 \%$ often do exercise and $8 \%$ are not
Table 1. Distribution of the bacterial isolates among the symptomatic and the asymptomatic patients

\begin{tabular}{|c|c|c|c|c|c|}
\hline $\begin{array}{c}\text { Types of bacterial } \\
\text { isolates }\end{array}$ & $\begin{array}{c}\text { Symptomatic } \\
\text { No (\%) }\end{array}$ & P-value & $\begin{array}{c}\text { Asymptomatic } \\
\text { No (\%) }\end{array}$ & P-value & $\begin{array}{c}\text { Total } \\
\text { No (\%) }\end{array}$ \\
\hline Escherichia coli & $5(19.2)$ & 0.19 & $5(31.2)$ & 0.31 & $10(25.0)$ \\
\hline CNS. & $12(46.1)$ & 0.46 & $3(18.7)$ & 0.19 & $15(37.5)$ \\
\hline Klebsiella. pneumonia & $5(19.2)$ & 0.19 & $0(0.0)$ & - & $5(12.5)$ \\
\hline Staphylococcu. aureus & $1((3.84)$ & 0.04 & $5(31.2)$ & 0.31 & $6(15.0)$ \\
\hline Streptococcu spp & $3(11.5)$ & 0.12 & $1(6.2)$ & 0.06 & $4(10.0)$ \\
\hline
\end{tabular}

CNS: Coagulase Negative Staphylococci

Table 2. Prevalence of UTI in relation to socio-demographic factors among asymptomatic and symptomatic patients

\begin{tabular}{|c|c|c|}
\hline Factors & $\begin{array}{l}\text { Asymptomatic } \\
\text { Positive } \\
\text { No (\%) }\end{array}$ & $\begin{array}{c}\text { Symptomatic } \\
\text { Positive } \\
\text { No }(\%)\end{array}$ \\
\hline \multicolumn{3}{|c|}{ Age } \\
\hline $20-35$ & $9(18.0)$ & $13(26.0)$ \\
\hline $36-45$ & $1(2.0)$ & $13(26.0)$ \\
\hline $46-55$ & $1(2.0)$ & $5(10.0)$ \\
\hline$\geq 56$ & $2(4.0)$ & $6(12.0)$ \\
\hline \multicolumn{3}{|c|}{ Sex } \\
\hline Male & $7(14.0)$ & $9(18.0)$ \\
\hline Female & $6(12.0)$ & $14(28.0)$ \\
\hline \multicolumn{3}{|c|}{ Family history of diabetics } \\
\hline Yes & $10(20.0)$ & $18(36.0)$ \\
\hline No & $40(80.0)$ & $32(64.0)$ \\
\hline \multicolumn{3}{|c|}{ Pancreatic disease } \\
\hline Yes & $1(2.0)$ & $3(6.0 .0)$ \\
\hline No & $49(98.0)$ & $47(94.0)$ \\
\hline \multicolumn{3}{|c|}{ Weight in kg } \\
\hline $30-40$ & - & - \\
\hline $41-50$ & $1(2.0)$ & - \\
\hline $51-60$ & $19(38.0)$ & $10(20.0)$ \\
\hline$>61$ & $30(60.0)$ & $40(80)$ \\
\hline \multicolumn{3}{|c|}{ Exercise } \\
\hline Yes & $43(86.0)$ & $41(82) .0$ \\
\hline No & $7(14.0)$ & $9(8.0)$ \\
\hline \multicolumn{3}{|c|}{ Favorite food } \\
\hline Rice & $16(32.0)$ & - \\
\hline Beans & $26(52.0)$ & $43(86.0)$ \\
\hline Swallow & $4(8.0)$ & - \\
\hline Others & $4(8.0)$ & $7(14.0)$ \\
\hline \multicolumn{3}{|c|}{ Diabetics knowledge } \\
\hline Yes & $50(100)$ & $49(98.0)$ \\
\hline No & - & $1(2.0)$ \\
\hline \multicolumn{3}{|c|}{ Knowledge about sign and symptoms of diabetics } \\
\hline Yes & $50(100)$ & $50(100)$ \\
\hline No & - & - \\
\hline \multicolumn{3}{|c|}{ Where information was gotten about diabetics } \\
\hline Clinic & $20(40)$ & $45(90)$ \\
\hline Media & $7(14)$ & - \\
\hline Family & $10(20)$ & $2(4)$ \\
\hline School & $11(22)$ & $2(4)$ \\
\hline Friends & $2(4)$ & $1(2)$ \\
\hline \multicolumn{3}{|c|}{ Treatment received } \\
\hline Yes & - & $50(100)$ \\
\hline No & $50(100)$ & - \\
\hline \multicolumn{3}{|c|}{ Marital status } \\
\hline Married & 23 & 40 \\
\hline Single & 27 & 5 \\
\hline Widow & 0 & 5 \\
\hline
\end{tabular}


Anejo-Okopi JA (2017) Bacterial and antibiotic susceptibility pattern of urinary tract infection isolated from asymptomatic and symptomatic diabetic patients attending tertiary hospital in Jos, Nigeria

doing exercise; and for the asymptomatic, only $20 \%$ of the group have family history of diabetics, $80 \%$ do not have family history of diabetics and $14 \%$ are not doing exercise.

The antimicrobial susceptibility patterns of gram negative bacteria (Table 3) isolates showed that E. coli is susceptible to Ciprofloxacin (60\%), Streptomycin (100\%), but resistant to Tarivid, Reflacine, Augmentin, Gentamycin, Ceporex, Nalidixic acid, Septrin and Ampicillin. K. pneumoniae was susceptible to streptomycin (100\%), while resistant to most of the antibiotics tested. CNS is susceptible to Ciprofloxacin (86.6\%), Norfloxacin (60\%), Gentamycin $(93.3 \%)$, Amoxicillin (86.66\%), Streptomycin (100\%), Rifampicin (100\%), Erythromycin (80\%), Chloramphenicol (66.6\%), Ampiclox (80\%) and Levofloxacin (100\%) whereas the gram positive (Table 4) showed; S. aureus is susceptible to Ciprofloxacin (83.33\%), Norfloxacin (50\%),

Table 3. Antimicrobial susceptibility pattern of the gram-negative bacteria $(n=15)$

\begin{tabular}{|c|c|c|c|}
\hline Antibiotics & Sensitivity & $\begin{array}{c}\text { Escherichia coli } \\
(n=10) \\
\text { No }(\%)\end{array}$ & $\begin{array}{c}\text { K. pneumoniae } \\
(n=5) \\
\text { No }(\%)\end{array}$ \\
\hline $\begin{array}{l}\text { Tarivid } \\
(10 \mathrm{ug})\end{array}$ & $\begin{array}{l}\mathrm{S} \\
\mathrm{R}\end{array}$ & $\begin{array}{l}3(30) \\
7(70)\end{array}$ & $\begin{array}{l}2(40) \\
3(60)\end{array}$ \\
\hline Reflacine (10 ug) & $\begin{array}{l}\mathrm{S} \\
\mathrm{R}\end{array}$ & $\begin{array}{l}2(20) \\
8(80)\end{array}$ & $\begin{array}{l}1(20) \\
4(80)\end{array}$ \\
\hline Ciprofloxacin (30 ug) & $\begin{array}{l}\mathrm{S} \\
\mathrm{R}\end{array}$ & $\begin{array}{l}6(60) \\
4(40)\end{array}$ & $\begin{array}{c}0(0) \\
5(100)\end{array}$ \\
\hline Augmentin (30 ug) & $\begin{array}{l}\mathrm{S} \\
\mathrm{R}\end{array}$ & $\begin{array}{l}1(10) \\
9(90)\end{array}$ & $\begin{array}{c}0(0) \\
5(100)\end{array}$ \\
\hline Gentamicin (10 ug) & $\begin{array}{l}\mathrm{S} \\
\mathrm{R}\end{array}$ & $\begin{array}{l}1(10) \\
9(90)\end{array}$ & $\begin{array}{l}1(20) \\
4(80)\end{array}$ \\
\hline Streptomycin (30 ug) & $\begin{array}{l}\mathrm{S} \\
\mathrm{R}\end{array}$ & $\begin{array}{c}10(100) \\
0(0)\end{array}$ & $\begin{array}{c}5(100) \\
0(0)\end{array}$ \\
\hline Ceporex (10 ug) & $\begin{array}{l}\mathrm{S} \\
\mathrm{R}\end{array}$ & $\begin{array}{l}3(30) \\
7(70)\end{array}$ & $\begin{array}{c}0(0) \\
5(100)\end{array}$ \\
\hline $\begin{array}{c}\text { Nalidixic acid (30 } \\
\text { ug) }\end{array}$ & $\begin{array}{l}\mathrm{S} \\
\mathrm{R}\end{array}$ & $\begin{array}{c}0(0) \\
10(100)\end{array}$ & $\begin{array}{c}0(0) \\
5(100)\end{array}$ \\
\hline Septrin (10 ug) & $\begin{array}{l}\mathrm{S} \\
\mathrm{R}\end{array}$ & $\begin{array}{l}3(30) \\
7(70)\end{array}$ & $\begin{array}{c}0(0) \\
5(100)\end{array}$ \\
\hline Ampicillin (10ug) & $\begin{array}{l}\mathrm{S} \\
\mathrm{R}\end{array}$ & $\begin{array}{l}1(10) \\
9(90)\end{array}$ & $\begin{array}{c}0(0) \\
5(100)\end{array}$ \\
\hline
\end{tabular}

S: Sensitive; R: Resistance

Table 4. The antimicrobial susceptibility pattern of gram positive bacteria $(n=25)$

\begin{tabular}{|c|c|c|c|c|}
\hline Antibiotics & Sensitivity & $\begin{array}{c}\text { CNS. } \\
(n=15) \\
\text { No }(\%)\end{array}$ & $\begin{array}{c}\text { S.aureus } \\
(n=6) \\
\text { No (\%) }\end{array}$ & $\begin{array}{c}\text { Strept. spp } \\
(\mathrm{n}=4) \\
\text { No }(\%)\end{array}$ \\
\hline $\begin{array}{l}\text { Ciprofloxacin } \\
\quad \text { (10 ug) }\end{array}$ & $\begin{array}{l}\mathrm{S} \\
\mathrm{R}\end{array}$ & $\begin{array}{c}13(86.66) \\
2(13.33)\end{array}$ & $\begin{array}{l}5(83.33) \\
1(16.66)\end{array}$ & $\begin{array}{c}4(100) \\
0(0)\end{array}$ \\
\hline $\begin{array}{l}\text { Norfloxacin } \\
\quad(30 \mathrm{ug})\end{array}$ & $\begin{array}{l}\mathrm{S} \\
\mathrm{R}\end{array}$ & $\begin{array}{l}9(60) \\
6(40)\end{array}$ & $\begin{array}{l}3(50) \\
3(50)\end{array}$ & $\begin{array}{l}2(50) \\
2(50)\end{array}$ \\
\hline $\begin{array}{c}\text { Gentamicin (10 } \\
\text { ug) }\end{array}$ & $\begin{array}{l}\mathrm{S} \\
\mathrm{R}\end{array}$ & $\begin{array}{c}14(93.33) \\
1(6.66)\end{array}$ & $\begin{array}{l}5(83.33) \\
1(16.66)\end{array}$ & $\begin{array}{c}4(100) \\
0(0)\end{array}$ \\
\hline $\begin{array}{l}\text { Amoxicillin } \\
(20 \mathrm{ug})\end{array}$ & $\begin{array}{l}\mathrm{S} \\
\mathrm{R}\end{array}$ & $\begin{array}{c}13(86.66) \\
2(13.33)\end{array}$ & $\begin{array}{l}5(83.33) \\
1(16.66)\end{array}$ & $\begin{array}{c}4(100) \\
0(0)\end{array}$ \\
\hline $\begin{array}{l}\text { Streptomycin } \\
\quad \text { (30 ug) }\end{array}$ & $\begin{array}{l}\mathrm{S} \\
\mathrm{R}\end{array}$ & $\begin{array}{c}15(100) \\
0(0)\end{array}$ & $\begin{array}{c}6(100) \\
0(0)\end{array}$ & $\begin{array}{c}4(100) \\
0(0)\end{array}$ \\
\hline $\begin{array}{c}\text { Rifampicin (10 } \\
\text { ug) }\end{array}$ & $\begin{array}{l}\mathrm{S} \\
\mathrm{R}\end{array}$ & $\begin{array}{c}15(100) \\
0(0)\end{array}$ & $\begin{array}{c}6(100) \\
0(0)\end{array}$ & $\begin{array}{c}4(100) \\
0(0)\end{array}$ \\
\hline $\begin{array}{l}\text { Erythromycin } \\
\text { (30 ug) }\end{array}$ & $\begin{array}{l}\mathrm{S} \\
\mathrm{R}\end{array}$ & $\begin{array}{c}12(80) \\
3(20)\end{array}$ & $\begin{array}{l}5(83.33) \\
1(16.66)\end{array}$ & $\begin{array}{c}4(100) \\
0(0)\end{array}$ \\
\hline $\begin{array}{l}\text { Chloramphenicol } \\
\text { (30 ug) }\end{array}$ & $\begin{array}{l}\mathrm{S} \\
\mathrm{R}\end{array}$ & $\begin{array}{c}10(66.66) \\
5(33.34)\end{array}$ & $\begin{array}{l}3(50) \\
3(50)\end{array}$ & $\begin{array}{l}3(75) \\
1(25)\end{array}$ \\
\hline $\begin{array}{l}\text { Ampiclox (10 } \\
\text { ug) }\end{array}$ & $\begin{array}{l}\mathrm{S} \\
\mathrm{R}\end{array}$ & $\begin{array}{c}12(80) \\
3(20)\end{array}$ & $\begin{array}{l}5(83.33) \\
1(16.66)\end{array}$ & $\begin{array}{c}4(100) \\
0(0)\end{array}$ \\
\hline $\begin{array}{l}\text { Levofloxacin } \\
\quad(10 \mathrm{ug})\end{array}$ & $\begin{array}{l}\mathrm{S} \\
\mathrm{R}\end{array}$ & $\begin{array}{c}15(100) \\
0(0)\end{array}$ & $\begin{array}{c}6(100) \\
0(0)\end{array}$ & $\begin{array}{c}4(100) \\
0(0)\end{array}$ \\
\hline
\end{tabular}

S: Sensitive; R: Resistance; CNS: Coagulase Negative Staphylococci
Gentamycin (83.33\%), Amoxicillin (83.33\%), Streptomycin (100\%), Rifampicin (100\%), Erythromycin (100\%), Chloramphenicol (75\%), Ampiclox (100\%), and Levrofloxacin (100\%).

\section{Discussion}

Despite the wide spread availability of antibiotics, urinary tract infection (UTI) remains the most common bacterial infection in human population [17]. Antibiotic resistance is a common phenomenon in developing countries where drugs are available freely without prescription. Finding from the present study showed that different bacterial species were isolated, meaning a prevalence rate of $40 \%$. This finding disagrees with the prevalence rate of $25.6 \%, 22 \%$, and $62 \%$ reported by Nedolisa, Ekweozo and Anejo in Jos, Ibadan and Maiduguri respectively $[18,19]$, but agrees with the report of Akinyemi, Ebie and Kemebradikumo who presented a prevalence rate of $38.6 \%$, $35.5 \%$ and $38 \%$ in Lagos, Jos and Niger Delta [2,20,21]. The high prevalence rates may be due to genuine factors like sexual intercourse, peer group influence, low socio-economic status among Nigerian Men and Women [18,22,23].

The highest bacteria in the present study was isolated in the age group 36-45 years and age group $>56$. Most of the bacteria isolated was in female $(67.5 \%)$, this finding corroborate the earlier finding of a work carried out in Nigeria and Ethiopia [19,24]. The higher prevalence of UTI among female population may be due to decrease in normal vaginal flora (Lactobacilli), less acidic $\mathrm{PH}$ of vaginal surfaces, poor hygienic condition, short and wider urethra and proximity to the anus [21]. Different studies in the general population showed that the etiologic agents of UTI belong mainly to the gram negative enteric bacteria [25]. In this present study, the most prevalent uropathogen isolated was Coagulase-Negative Staphylococci which accounted for $37.5 \%$ of the isolated bacteria followed by E. coli which accounted for $25 \%$ of the isolated bacteria. This finding disagrees with the earlier work reported in Nigeria and Ethiopia $[6,19,24]$. The higher isolation rate of Coagulase-Negative Staphylococci in the present study could be explained as contamination during specimen's collection and/or change in pattern of infection in diabetic patients [21].

Finding from the present study also revealed that more than one type of bacteria (mixed) was isolated in four (4) of the urine specimens cultured in the study. This agrees with the earlier finding in Nigeria and Bangladesh $[25,26]$. Out of the 100 urine samples investigated, a total of $32(32 \%)$ yielded significant growth of single organism, 4 (4\%) mixed growth and $60(60 \%)$ yielded no growth. This finding corroborates also with the finding of Sharmin in Bangladesh who reported $38.5 \%$ single growth and $4 \%$ mixed growth [21]. Some microbiologist regards polymicrobial growth as contamination [24]. However, polymicrobial growth from midstream urine have been found among patients with underlying disorder that interferes with free flow of urine [27]. Finding from the present study revealed also that there is a significant difference in the bacteria isolated among the symptomatic and the asymptomatic group as shown in Table 1 .

The percentage of resistance of Escherichia coli in this study is alarming giving that it was resistance to Tarivid (70\%), Reflacine (80\%), Augmentin (90\%), Gentamycin (90\%), Ceporex (70\%), Nalidixic acid (100\%), Septrin (70\%), and Ampicillin (90\%) while it was susceptible to Streptomycin (100\%) and Ciprofloxacin (60\%). Klebsiella pneumoniae showed elevated level resistance to most of the antibiotics and was only susceptible to Streptomycin (100\%) as shown in Table 3. It is a wellknown fact that Klebsiella spp. is inherently resistant to; Ampicillin, Cephalosporin and Aminoglycosides due to the increasing acquisition of resistant plasmid [16]. 
Anejo-Okopi JA (2017) Bacterial and antibiotic susceptibility pattern of urinary tract infection isolated from asymptomatic and symptomatic diabetic patients attending tertiary hospital in Jos, Nigeria

This finding agrees with the earlier study carried out in India by Manikandan who reported that E. coli was resistant to Gentamycin, Nalidixic acid and it was sensitive to Ciprofloxacin and Klebsiella pneumoniae was resistant to Nalidixic acid [14]. The present study also agrees with the earlier finding of Gizachew and Anejo who reported that E. coli was susceptible to Ciprofloxacin in Ethiopia and Maiduguri [14]. The present finding revealed also that E. coli was resistant to Gentamycin, which is in contrast with earlier finding [19]. Finding of the present study revealed that most of the antibiotics used were susceptible to the gram-positive bacteria isolated as shown in Table 4. Coagulase-Negative Staphylococci were susceptible to; Ciprofloxacin (86.66\%), Norfloxacin (60\%), Gentamycin (93.3), Amoxicillin (86.7\%), Streptomycin (100), Rifampicin (100\%), Erythromycin (80\%), Chloramphenicol (66.6\%), Ampiclox (80\%) and Levofloxacin (100\%). Coagulase-Negative Staphylococcus that was isolated in the study does not resist any of the antibiotics. On the other hand, S aureus showed (50\%) resistance to Norfloxacin and Chlorophenicol respectively but it was susceptible to the rest of the antibiotics. Streptococcus spp. shows $50 \%$ resistance to Norfloxacin and 25\% resistance to Chloramphenicol as shown in Table 4 . The present finding agrees with the finding reported by Gizachew, et al. [24] that Coagulase-Negative Staphylococcus was susceptible to Amoxicillin, Ciprofloxacin, Chloramphenicol, Gentamycin and Erythromycin, S aureus was susceptible to Amoxicillin and Gentamycin [21]. The present finding also corroborate the finding of Anejo-Okopi, et al. [19] who reported that S. aureus was susceptible to; Ciprofloxacin, Gentamycin and Amoxicillin [19]. Finding from the present study revealed that the bacteria isolated in the study were strongly susceptible to Streptomycin. This is in contrast with the findings of Kemebradikumo, et al. [21] and Gizachew, et al. [24] who reported Nitrofurantoin and Amoxicillin respectively as their most susceptible antibiotics $[21,28]$.

\section{Conclusion}

In conclusion, significant bacteriuria was isolated in $65 \%$ and $35 \%$ of symptomatic and asymptomatic diabetic patients respectively. Urinary tract bacteria base on this finding in asymptomatic diabetic patients should not be neglected and follow up studies are required to supplement the present finding for appropriate management of urinary tract bacteria in diabetic patients. Also, the gram-negative bacteria isolated in the study resist most of the antibiotics used while gram positive bacteria were highly susceptible to the used. There is a significant difference between the bacterial isolates of the symptomatic and the asymptomatic diabetic patients.

\section{Acknowledgement}

Our profound gratitude goes to all the Diabetic patients who consented to the study at Bingham University Teaching Hospital Jos, Nigeria for their samples. We remain grateful to Mrs. Liman B Fatima of the Central Diagnostic Laboratory NVRI Vom for their immense support during the bench work.

\section{Conflicting interest}

No conflict of interest.

\section{References}

1. Morgan MG, McKenzie H (1993) Controversies in the laboratory diagnosis of community acquired urinary tract infection. Eur J Clin Microbiol Infect Dis 12: 491504. [Crossref]

2. Ebie MY, Kandakai-Olukemi YT, Ayanbadejo J, Tanyigna KB (2001) Urinary tract infection in a Nigerian military Hospital. Nigerian Journal of Microbiology 15: 31-37.
3. Hooton TM, Stamm WE (1997) Diagnosis and treatment of uncomplicated urinary tract infection. Infect Dis Clin North Am 11: 551-581. [Crossref]

4. Omoregie R, Erebor JO, Ahonkhai I, Isobor JO, Ogefere HO (2008) Observed changes in the prevalence of uropathogens in Benin City, Nigeria. J Med Lab Sci 62: 29-31.

5. Njunda AL, Assob NJC, Nsagha SD, Nde FP, Kamga FHL, et al. (2012) Uropathogens from diabetic patients with asymptomatic bacteriuria and Urinary tract infections. Sci JMicrob 1: 141-146.

6. Kolawole, A.S., Kolawole, O.M., Kandake-Olukemi, Y.T., Babatunde, S.K. and Durowade, K. (2009). Prevalence of urinary tract infection (UTI) among patients attending Dalhatu Araf specialist Hospital, Lafia, Nassarawa State, Nigeria. Int J Med Med Sci 1: 163-169.

7. Bonadio M, Costarelli S, Morelli G, Tartaglia T (2006) The influence of diabetes mellitus on the spectrum of uropathogens and the antimicrobial resistance in elderly adult patients with urinary tract infection. BMC Infect Dis 6: 54-58. [Crossref]

8. Sahib AKY (2008) Study of ciprofloxacin resistant Escherichia coli in type 2 diabetic patients with symptomatic urinary tract infections. Iraq J Comm Med 21: 58-63.

9. Hasan MK, Nazimuddin K, Ahmed AKMS, Sarker RSC, Haque M, et al. (2007) Differences in a bacteriological and antibiotic sensitivity patterns in UTI among hospitalized diabetic and non-diabetic patients. J Medicine 8: 10-13.

10. Al-Rubeaan KA, Moharram O, Al-Naqeb D, Hassan A, Rafiullah MR (2013) Prevalence of urinary tract infection and risk factors among Saudi patients with diabetes. World $J$ Urol 31: 573-578. [Crossref]

11. Bronsema DA, Adams JR, Pallares R, Wenzel RP (1993) Secular trends in rates and etiology of nosocomial urinary tract infections at a university hospital. J Urol 150: 414-416. [Crossref]

12. Jacobs LG (1996) Fungal urinary tract infections in the elderly: Treatment guidelines. Drugs Aging 8: 89-96. [Crossref]

13. Schneider PF, Riley TV (1996) Staphylococcus saprophyticus urinary tract infections: Epidemiological data from Western Australia. Eur J Epidemiol 12: 51-54. [Crossref]

14. Manikandan S, Genesapandian S, Singh M, Kumaraguru S (2011) Antimicrobial susceptibility pattern of urinary tract infection causing human pathogenic bacteria. Asian J Med Sci 3: 56-60.

15. National Committee for Clinical Laboratory Standards (2004) Methods for dilution, Antimicrobial Susceptibility tests for Bacteria that grow aerobically: Performance standards for Antibiotics Testing: twelfth Informational Supplement (ISBN 1 - 56238 - 454 - 6). NCCLS publication M100-S12.

16. Baur AW, Kirby WM, Sherris JC, Turch M (1966) Antibiotic susceptibility testing by a standarized single disk method. Am J Clin Pathol 45: 493-496. [Crossref]

17. Royles JR, Walsh M (1992) Watson's medical surgical nursing and related physiology. 4th edition. London Bailliere Tindall. 1992, SBN-10: 0702015156; ISBN-13: pp. 978982

18. Ekweozor CC, Onyemenen TN (1996) Urinary Tract Infection in Ibadan, Nigeria: causative organism and anti-microbial sensitivity pattern. Afr J Med Med Sci 25: 165169

19. Anejo-Okopi AJ, Okwori AE, Eze MI, Onaji AI, Ali M, et al. (2015) Prevalence and antibiotic resistance pattern of urinary tract infection among symptomatic patients attending University of Maiduguri Teaching Hospital, North East Nigeria. EJARBLS 3: 2056-5984

20. Akinyemi KO, Alabi SA, Taiwo MA, Omonigbehin EA (1997) Antimicrobial susceptibility pattern and plasmid profiles of pathogenic bacteria isolated from subjects with urinary tract infections in Lagos, Nigeria Quarters. J Hosp Med 1: 7-11.

21. Kemebradikumo P, Oluwatoyosi O, Onyaye EK (2012) Antimicrobial susceptibility pattern of microorganisms associated with urinary tract infection in the Niger Delta region of Nigeria. Afr J Microbiol Res 23: 4976-4982.

22. Stamm WE, Counts GW, Running KR, Fihn S, Turck M, et al. (1982) Diagnosis of coliform infection in acutely dysuric women. $N$ Engl J Med 307: 463-468. [Crossref]

23. Hooton TM (2000) Pathogenesis of urinary tract infections: an update. J Antimicrob Chemother 46: 1-7.

24. Gizachew Y, Daniel A, Yimtubezinash W, Chandrashekhar G (2012) Urinary tract infection: Bacterial etiplogies, drug resistance profile and associated risk factors in diabetic patients attending Gondar university hospital, Gondar, Ethiopia. Eur J Exp Biol 2: 889-898. 
Anejo-Okopi JA (2017) Bacterial and antibiotic susceptibility pattern of urinary tract infection isolated from asymptomatic and symptomatic diabetic patients attending tertiary hospital in Jos, Nigeria

25. Andriole VT, Patterson TF (1991). Epidemiology, natural history, and management of urinary tract infections in pregnancy. Med Clin North Am 75: 359-373.

26. Adeyeba OA, Omosihgo PO (2007) Bacterial urinary tract infections in patients with diabetes mellitus. Int J Trop Med 2: 89-92.
27. Sharmin S (2005) Use of chromogenic media for detection of uropathogen, $M$ philosophy (Microbiology) Thesis, Bangabandhu Sheikh Mujib Medical University, Bangladesh, pp. 1-198.

28. Griebling TL (2005) Urologic diseases in America project: trends in resource use for urinary tract infections in women. J Urol 173: 1281-1287

Copyright: (C2017 Anejo-Okopi JA. This is an open-access article distributed under the terms of the Creative Commons Attribution License, which permits unrestricted use, distribution, and reproduction in any medium, provided the original author and source are credited. 